\title{
救命救急センターにおける救急医療に対する薬剤師の関与
}

\author{
今井 徹, ${ }^{*}$ 吉田善一
}

\section{Involvement of Pharmacists in Medical Care in Emergency and Critical Care Centers}

\author{
Toru Imai* and Yoshikazu Yoshida \\ Department of Pharmacy, Nihon University Itabashi Hospital; \\ 30-1 Ohyaguchi-kami-cho, Itabashi-ku, Tokyo 173-8610, Japan.
}

(Received November 16, 2015)

\begin{abstract}
Emergency and critical care centers provide multidisciplinary therapy for critically ill patients by centralizing the expertise and technology of many medical professionals. Because the patients' conditions vary, different drug treatments are administered along with surgery. Therefore, the role of pharmacists is important. Critically ill patients who receive high-level invasive treatment undergo physiological changes differing from their normal condition along with variable therapeutic effects and pharmacokinetics. Pharmacists are responsible for recommending the appropriate drug therapy using their knowledge of pharmacology and pharmacokinetics. Further, pharmacists need to determine the general condition of patients by understanding vital signs, blood gas analysis results, etc. It is therefore necessary to conduct consultations with physicians and nurses. The knowledge required for emergency medical treatment is not provided during systematic training in pharmaceutical education, meaning that pharmacists acquire it in the clinical setting through trial and error. To disseminate the knowledge of emergency medical care to pharmacy students, emergency care training has been started in a few facilities. I believe that medical facilities and universities need to conduct joint educational sessions on emergency medical care. Moreover, compared with other medical fields, there are fewer studies on emergency medical care. Research-oriented pharmacists must resolve this issue. This review introduces the work conducted by pharmacists for clinical student education and clinical research at the Emergency and Critical Care Center of Nihon University Itabashi Hospital and discusses future prospects.
\end{abstract}

Key words — emergency medical care; pharmacist; student education; clinical study

\section{1. はじめに}

救急医療においては，多発外傷，意識障害，急性 薬物中毒，心肺停止など重症度や緊急度の高い患者 に対して，多くの医療スタッフが専門性と技術を集 結し，集学的な治療を行っている．患者の病態は多 岐にわたり，外科的処置とともに様々な薬物治療が 行われ，ハイリスク医薬品が汎用されるため薬剤師 の積極的な関与が求められている. 昨今では多くの 医療機関で薬剤師が救急医療に関与しているが, 1 1) 日本大学医学部附属板橋病院救命救急センター（以 下, 当センター）では平成 3 年の開設当初より, 薬 剂師が他の医療スタッフとともに 24 時間体制で救

日本大学医学部附属板橋病院薬剤部（下173-8610 東京 都板橋区大谷口上町 30-1)

*e-mail: imai.toru@ nihon-u.ac.jp

本総説は, 日本薬学会第 135 年会シンポジウム S51 で 発表した内容を中心に記述したものである.
急搬送された患者の初期診療を行う初療から退院ま で救急医療に携わり，チーム医療の一員として総合 的な薬学的管理を行ってきた. ${ }^{2)}$

本稿では, 救命救急センターにおける救急医療に 対する薬剤師の関与について, 当センターで行って いる臨床業務, 薬学生への教育, 臨床研究について 紹介し, 今後の救急医療における薬剤師の展望につ いて考察したい.

2. 救命救急センターにおける薬剤師の臨床業務 救命救急センターは, 生命の危機に瀕した患者に 対して迅速かつ高度な医療の提供が要求される。薬 剂師は医薬品の知識を全般的に網羅したジェネラリ ストの能力に加え，救急医療に特有の薬物治療や多 臓器不全時の薬物投与設計などの知識が求められ る. 重篤な患者が常時搬送されてくる救命救急セン ターにおける薬剤師の役割は多岐に渡っており, 当 センターでは大きく 6 項目の臨床業務を行っている 

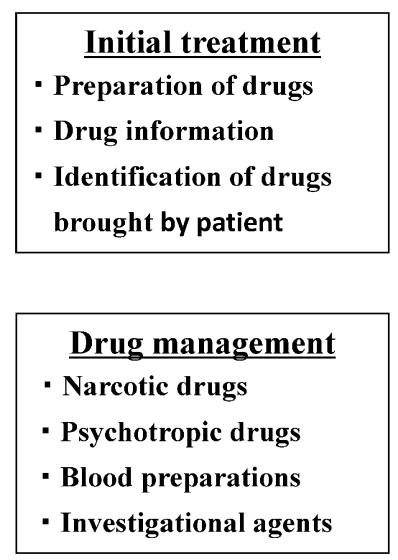
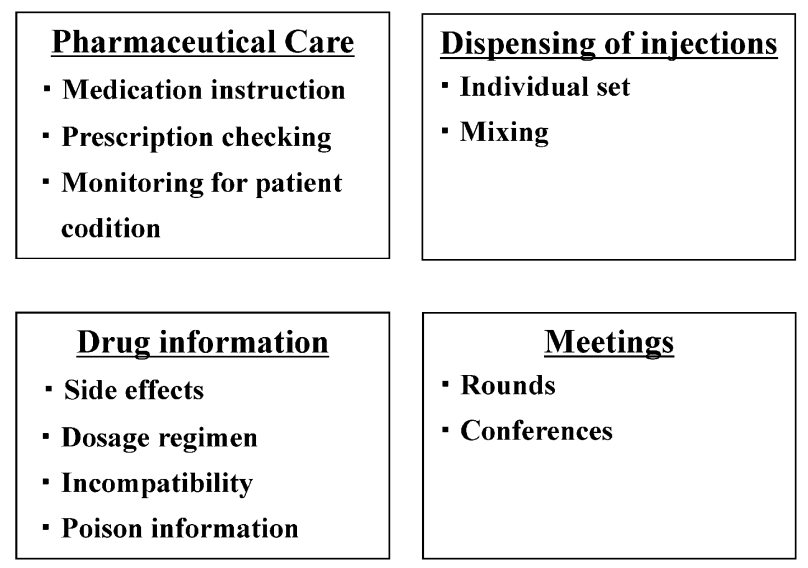

Fig. 1. Roles of Pharmacists in Emergency and Critical Care Center

(Fig. 1)。それぞれの業務は，薬剤師の職能を十分 に発揮し得るものであり, 救急医療において必要不 可欠なものと考えているが, 本稿では初療業務及び 医薬品情報提供について紹介する.

\section{2-1. 初療業務 当センターでは, 救急車から} の患者搬送時から医師, 看護師とともに薬凨師も患 者の治療に参画している. 病院に到着した患者は, 最初に初療室に運ばれ, 全身状態の把握とバイタル の安定化のための治療が行われる。 その中で, 薬剤 師は使用薬剤の調製，薬剤投与の時間計測と記録， バイタルサインや血液ガスに基づき患者の状態に応 じた使用薬剤の推奨, 搬送患者の服用薬の確認など の業務を行っている (Fig. 2).

迅速な対処が要求される初療では, 医薬品に関す る指示はすべて口頭で行われ，その指示に基づいて 薬剤師が薬剤の準備及び調製を行っている。初療に 薬剂師が参画していない多くの施設では, 医師, 看 護師がこれらの作業を行っていると思われるが，薬 剂師が関与することにより医師や看護師が治療や処 置に専念できる環境を提供することができている.

また，医師の口頭指示をダブルチェックすることが できるため, 医療安全の観点でも薬剤師が大きく貢 献している.さらに, 搬送された患者の服用薬の確 認も薬剤師の重要な役割の 1 つである。意識障害を 呈した患者が搬送された場合, 医師は意識障害の原 因を考えながら処置や検査を進めていくが，それと 同時に薬剂師は患者の服用薬の確認を行っている. 意識障害を引き起こす可能性のある薬剂を服用して いる場合は，その薬剤の情報提供を直ちに行い，医 師が病態の原因検索や治療を円滑に進めるためのサ
ポートを行っている.

救急医療においては心肺停止患者の搬送も多く, 初療に参加する薬剤師は日本救急医学会の Immediate Cardiac Life Support (ICLS) コースを受講し, 心肺蘇生法のアルゴリズムを理解している。 また, 薬剤師は薬に関連する業務に限定せず，他職種とと もに患者の脱衣や暴れる患者を押さえたりと, 医療 者として行えることは積極的に関与している．この ように, 薬剤の知識だけではなく, 他職種と共通認 識を持ち，スキルミックスを実践することが初療に おけるチーム医療には重要となる.

2-2. 医薬品情報提供初療により患者の状態 が安定したあとは, intensive care unit（ICU）にて 病態の精査及び集中治療が行われる. ICU では患 者の状態に応じて様々な薬物治療が行われるが, 状 態が急激に変化することも多く, 最適な薬剤の投与 量, 投与方法, 配合変化等の情報を迅速に提供する ことが求められる. 当センターでは, 薬剤師が医師 や看護師とともに患者の状態を確認しながらディス カッションを行い, 最適な医薬品情報提供を行って いる.

われわれは平成 21 年 8 月から 12 月の 5 力月間 に, 当センターにおいて薬剤師が医師, 看護師に

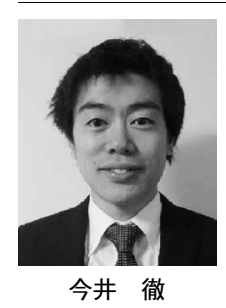

日本大学医学部附属板橋病院薬剂部. 博士 (薬学)。2006 年日本大学大学院 薬学研究科博士前期課程修了後, 日本 大学医学部附属板橋病院入職. 2014 年 日本大学大学院薬学研究科博士後期課 程修了. 現在, 救命救急センター担当 薬剂師として救急集中治療に従事. 救 急認定薬剂師, 感染制御専門薬剤師. 


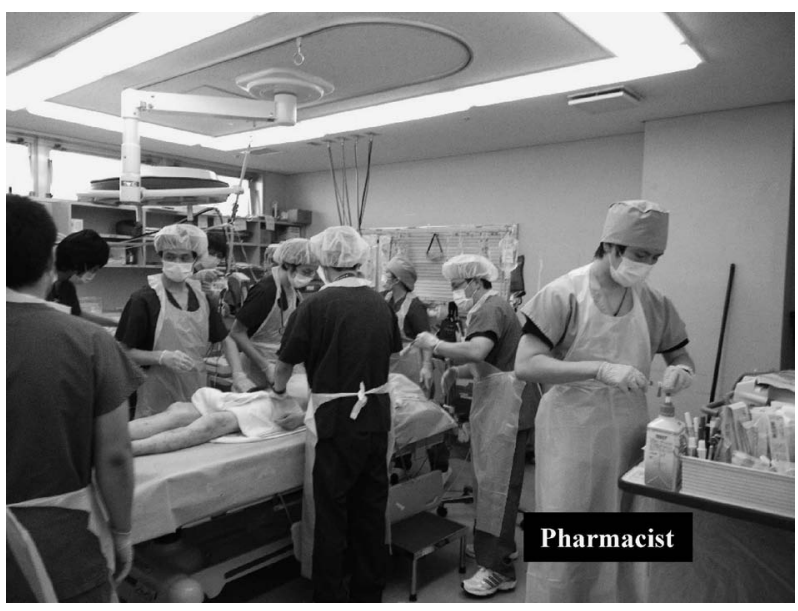

Fig. 2. Involvement of Pharmacists in Initial Treatment

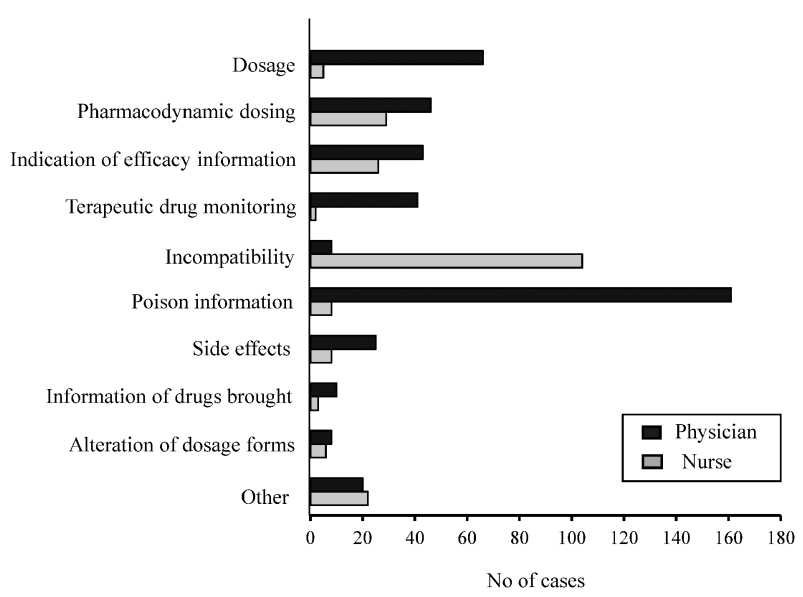

Fig. 3. Drug Information Provision

行つた医薬品情報提供の内容について解析を行つ た. ${ }^{3)}$ 医師，看護師に対する医薬品情報提供内容 は，医師に対しては中毒情報が 161 件と最も多く， 次に投与量 66 件，投与方法 46 件であり (Fig. 3), 治療や処方設計に関する情報提供が多く，迅速な治 療に寄与していると思われる．看護師に対しては配 合変化に関する内容が 104 件と多く, 次に投与方法 29 件であった。配合変化によるルートの閉塞は ルート確保が困難な重症患者にとっては致命的であ るため，看護師にとっては配合変化の情報は重要で あり，薬剂師が配合変化の情報を提供することは， 薬物治療を実施するうえでのリスク回避に寄与して いると考えられる。このように，薬剤師は様々な情 報提供を行っているが，実際に当センターの医師は 救急医療に薬剤師が参画し，リアルタイムに医薬品 情報提供を受けることの有用性を報告しており, ${ }^{4)}$
医薬品情報提供は薬剂師の職能を活かし，救急医療 に大いに貢献することのできる分野であると考える.

\section{3. 救命救急センターにおける薬学生に対する教} 育

近年，各医療施設において臨床に係わる高い実践 能力を有し，医療に貢献できる薬剤師の育成を目的 に特色ある臨床教育が実施されている，当センター では救急チームの中で活躍できる薬剤師の育成を目 指した参加型救命救急実習を行っている. 実習内容 は指導薬剤師とともに初療，薬剤管理指導，医薬品 情報提供，カンファレンスや回診を見学するととも に，心肺蘇生法や急性薬物中毒などの救急医療に必 要な知識について講義を行っている．初療室では, 多職種連携により行われる初療の様子や薬剤師が救 急チーム内で担っている役割について見学を行って いる（Fig. 4)。また，ICU 入室後の患者の状態を 確認しながら学生と集中治療に関するディスカッ ションを行い，救急医療，集中治療にわたりシーム レスな教育を心がけている。ささら，一般病棟とは 異なり多臓器不全や循環不全の患者が多く, 救急集 中治療特有の患者状態を考慮した薬学的管理が必要 なことを，実際の薬剂管理指導業務を通じて教育を 行っている.

われわれは，救命救急実習を受けた学生を対象に 救急医療に対する認識や理解度, 実習内容について 事前・事後アンケート調査を行い，学習効果及び実 習の有用性について評価を行っている．事前アン ケートでは, 多くの学生が救急医療に興味を示して いることが明らかになったが，救命救急センターの 薬剤師業務については約 7 割が知らないと回答し た．事後アンケートでは救命救急センターでの薬剤 師の業務や役割を十分に理解し，救急におけるチー ム医療に薬剤師は必要であるとの意見が多くを占 め, 約 9 割が救命救急実習に満足できたと回答し た. また，救急医療の現場で薬剤師として働きた い，チーム医療の重要性や薬剤師の更なる可能性を 実感できたなど，薬剤師になるという認識や自覚を 強く促す意見が多く得られた。また，心肺蘇生法や 薬物中毒に関する理解度は実習前と比較して有意な 上昇が認められた（Fig. 5)。救命救急実習は救急 医療に必要な知識を身につけるとともに，実習意欲 の向上に寄与し，臨床実習として有用であると思わ れる. 現在, 先進的な大学においても, 救急医療に 
(A)

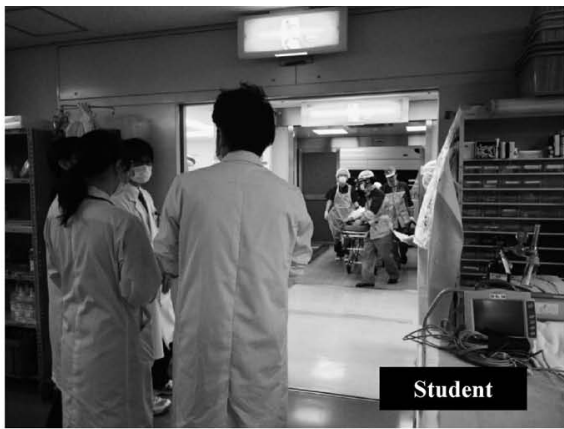

(C)

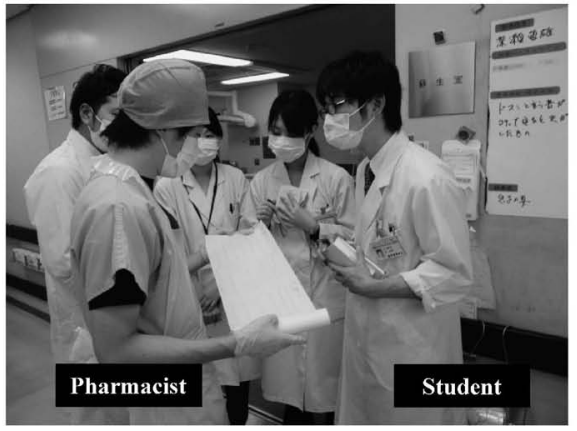

(B)

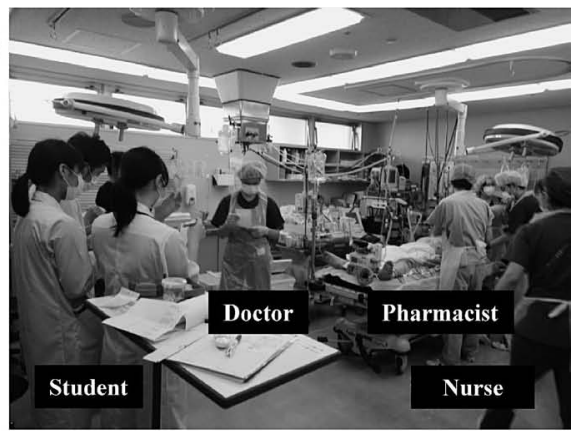

(D)

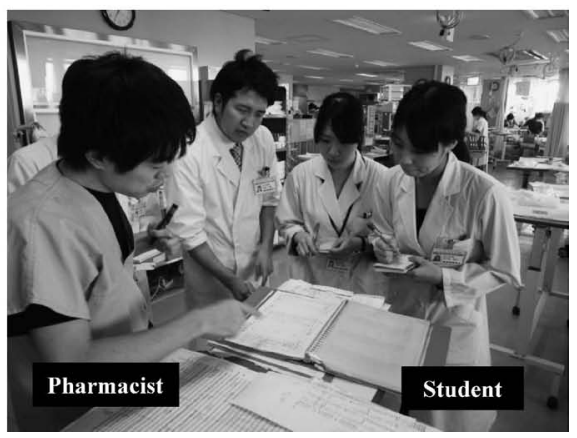

Fig. 4. Work Flow Taught in Medical Emergency Education

(A) Enter from the ambulance to the emergency room; (B) observation of the role of other professionals in initial treatment; (C) commenting on the patient's condition; (D) monitoring the patient's condition in the ICU.

(A) Cardiopulmonary resuscitation

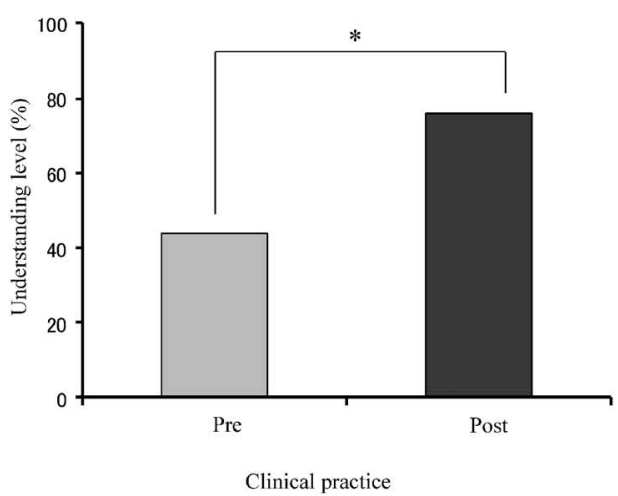

(B) Acute drug intoxication

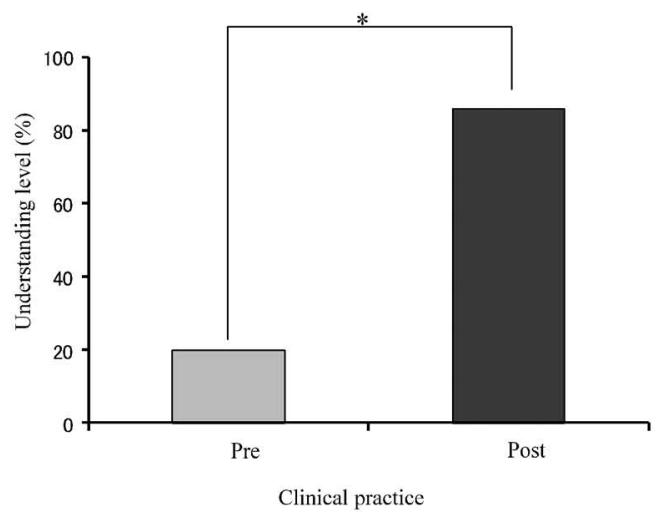

Fig. 5. Evaluation of Medical Emergency Education

(A) Understanding the level of cardiopulmonary resuscitation; (B) understanding the level of acute drug intoxication. Fisher's exact test was used in analysis. ${ }^{*} p<0.05$.

関する実習が行われており,5) 今後は大学と臨床現 場が一体となって救急医療における臨床教育の充実 と普及が喫緊の課題であると考える。

4. 全身性炎症反応症候群における薬物治療に関 する臨床研究

救急集中治療を受けている患者の特徵として, 強 い侵襲により血管透過性の充進やサードスペースの 形成，大量の浸出液などの様々な反応を示す。さら に，病態の進行により循環不全や播種性血管内凝固
症候群が起こり，血液浄化や急速大量輸液などの治 療が行われるため，慢性期の患者とは異なり，著し く薬物代謝排泄能が変化している。 しかし，医薬品 の承認時の薬物動態パラメー夕は健康成人を用いた ものが多く，侵襲時における薬物動態や至適薬物投 与法についてはエビデンスが少ないのが現状であ る. 薬剤師は薬理学や薬物動態学の知識を駆使し, 最善の薬物治療を推奨する責務があり, 研究マイン ドを持ち救急集中治療における薬物治療のエビデン 
(A) $\mathrm{CL}_{\mathrm{vcm}}$

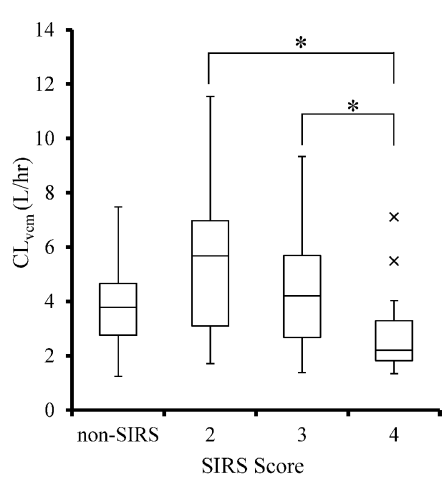

(B) $\mathrm{Vd}$

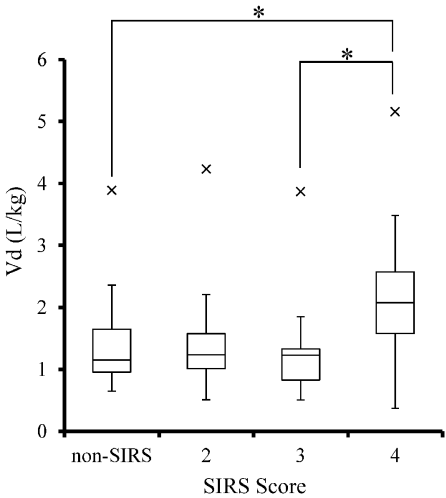

(C) $\mathrm{T}_{1 / 2}$

Fig. 6. Pharmacokinetic Parameters of Vancomycin, (A) $\mathrm{CL}_{\mathrm{vcm}}$, (B) Vd, and $(C) \mathrm{T}_{1 / 2}$

Kruskal-Wallis one-way analysis of variance followed by the Steel-Dwass multiple-comparison test was used in analysis. ${ }^{*} p<0.05$.

スの構築に努めなければならない.

近年，重症感染症や外傷，膵炎，手術などの侵襲 が加わったときに生じる全身性の炎症反応の病態と して, 全身性炎症反応症候群（systemic inflammatory response syndrome; SIRS) が提唱されている. 現在までにSIRS が薬物動態にどのような影響を及 ぼすか詳細な検討はあまり行われていないが，われ われは SIRS が塩酸バンコマイシン（vancomycin; VCM）の薬物動態へ与える影響について検討を 行ったので紹介する.

\section{4-1. SIRS が VCM の薬物動態へ与える影響6)}

ICU では糖尿病や肝硬変, 低栄養などの疾患を 持つ易感染宿主の患者が多く, 人工呼吸器や血管内 留置カテーテルなどの医療器具による皮膚や粘膜な どの生体防御バリア破綻と相まって, 感染症が高頻 度で発症する. ICU で感染症を引き起こす起因菌 として Methicillin-resistant Staphylococcus aureus （MRSA）が多くを占め, 診療ガイドラインにおい て, VCM が第一選択薬として推奨されている.7) われわれは SIRS が VCM の薬物動態へ及ぼす影響 を明らかにするため, SIRS スコアと薬物動態パラ メータとの関係について検討を行つた。 その結果,

$\mathrm{CL}_{\mathrm{vcm}}$ はスコア 2 では上昇が認められたが，スコア 4 ではスコア 2, 3 と比べ, 有意な低下を示した (Fig. 6)。これは, SIRS の病態の進行とともに, 循環動態は高心拍出状態となり, 腎血流量と腎糸球 体ろ過速度が増加するためにスコア 2 では $\mathrm{CL}_{\mathrm{vcm}}$ が増大したと考えられ, さらに侵襲が進行すると, 心臓や腎臓の臓器不全を呈し, スコア 3, 4 の患者
では $\mathrm{CL}_{\mathrm{vcm}}$ が低下傾向となったと考えられる. ま た，Vd は非 SIRS からスコア 3 までの患者では大 きな変化はなかったが, 炎症反応の充進したスコア 4 で増大が認められた。これは, SIRS の進行に伴 い血管透過性の充進が引き起こされ, サードスペー スが形成されたことにより Vd が増大したと考えら れる。ささらに, $\mathrm{T}_{1 / 2}$ は $\mathrm{Vd} や \mathrm{CL}_{\mathrm{vcm}}$ の影響を受け, SIRS が進行したスコア 4 では延長が認められた.

本研究において, SIRS はVCM の薬物動態パラ メータに影響を与え, 各 SIRS スコアによりその影 響は異なることが示唆された。つまり，侵襲を受け ている重症患者に対して, 適切な VCM の投与設計 を行うためには, 腎機能の把握だけでは不十分であ り, 生体の炎症反応の状態を加味しておく必要があ ると思われる. 今後, さらに SIRS 患者の薬物動態 について検討を行い, 救急集中治療領域における最 適な薬物投与方法の確立を進めていきたいと考えて いる.

\section{5. 今後の展望}

救急医療におけるチーム医療の必要性は高く, 薬 物治療に対する薬剤師の役割や責任は大きい. 平成 20 年 4 月の診療報酬改定に伴い, 救命救急セン ター等に入院している意思疎通のとれない患者に対 して適切な薬学的管理を行うことで薬剤管理指導料 の算定が可能となった. さらに, 日本臨床救急医学 会の救急認定薬剤師制度設立とも合わさり, 救急医 療に対する薬剤師の積極的な参画が進んでいる.し かし, 救急医療における薬剂師の役割はいまだ確立 しておらず, 各医療施設で試行錯誤しているのが現 
状だと思われる，また，薬学部においては救急医療 に関する教育をほとんど受けておらず，臨床現場で 初めて救急医療を学ぶ薬剤師も多い。このような点 から，救急医療に従事する薬剤師のネットワークの 構築や医療機関と大学とが連携した教育体制の構築 が必要と考える，近い将来，教育を受けた未来の薬 剂師が救急チームに参画し, 明日の救急医療の担い 手として活躍することを期待したい。また，薬剤師 がさらに救急医療に関与するためには薬物治療の発 展に寄与するエビデンスの発信が必要不可欠であ る.これらの臨床, 教育, 研究の 3 本柱を強化する ことにより, 医療チーム内での薬凨師の存在価值を 確立し，患者に対する適切な治療や多職種間の円滑 な連携を推進していくことが重要だと考える.

利益相反＼cjkstart開示すべき利益相反はない.

\section{REFERENCES}

1) Unei H., Minemura A., Kuwahara T.,
Nishizawa K., Hirata K., Ishikawa M., Endo S., J. Jpn. Soc. Emer. Med., 48, 319-322 (2012).

2) Chuma M., Imai T., Kikuchi N., Yoshida Y., J. Jpn. Soc. Hosp. Pharm., 49, 1325-1327 (2013).

3) Imai T., Chuma M., Kurauchi K., Kikuchi N., Yoshida Y., Tanjoh K., J. Jpn. Soc. Hosp. Pharm., 12, 412-419 (2009).

4) Kinoshita K., Tanjoh K., J. Abdominal Emergency Medicine, 30, 41-44 (2010).

5) Zamami Y., Sagara H., Imai T., Hara N., Takemoto A., Koyama T., Nawa H., Kitamura Y., Ujike Y., Sendo T., Journal of Japanese Society for Clinical Information on Parenteral Drugs, 4, 11-21 (2015).

6) Irikuchi J., Imai T., Yoshida Y., Orii T., Yakugaku Zasshi, 135, 745-751 (2015) .

7) The Japanese Society of Intensive Care Medicine, Committee of Spesis Registry, J. Jpn. Soc. Intensive Care Med., 20, 124-173 (2013) . 